\title{
Financial Literacy and Investments in Higher Education *
}

\author{
Fernando Lopez ${ }^{\dagger}$
}

This version: September, 2014

\begin{abstract}
Using a rich data set from a large U.S. non-profit organization, I find that low income post-secondary students are poorly informed about three main financial aspects of their higher education: future income, financing costs and opportunity cost of being enrolled. This result holds for students who are academically talented, have been exposed to financial education (including a semester-long personal finance class) and relevant financial experiences. Furthermore, the first round of results of a randomized controlled trial $(\mathrm{N}=117)$ suggests that an hour-long financial education workshop on the main financial aspects of college increases students' GPA by 0.2 points ( $p$-value $=0.15$ ) and their ability to receive financial aid from the non-profit organization by 11.4 percentage points ( $p$-value $=0.25)$.
\end{abstract}

JEL: G11, D14, J24, R20

Keywords: financial literacy, financial education, financial aid, human capital, randomized controlled trial.

\footnotetext{
* I am very grateful to the staff members of the Scholarship Foundation of St. Louis for providing access to the data that I use in this study. I am especially thankful to Faith Sandler and Maria Rebecchi for the several discussions about the Foundation's programs and target population; and to Rob Foley for his help to access and use the data. I am also thankful for the comments and suggestions from seminar participants at Washington University (business economics brown bag), Universidad Alberto Hurtado, Universidad Adolfo Ibáñez, Missouri Department of Higher Education and staff and board members of the Scholarship Foundation of St. Louis. All errors are mine.

${ }^{+}$School of Business and Economics, Universidad Alberto Hurtado. Email: felopez@uahurtado.cl
} 


\section{Introduction}

Higher education is a key investment opportunity for young individuals. It is a major source lifetime well-being that arises from a higher expected income (Avery and Turner, 2012) and a wide array of non-pecuniary benefits (Oreopoulos and Salvanes, 2011). Yet, there is little known about the extent to which students understand and take into consideration the financial aspects of this decision. Addressing this question is important because investments in higher education are highly complex and this raises the possibility that individuals engage in suboptimal decision making. Indeed, students have to decide whether or not they want to enroll in a post-secondary institution, and if they do, they face a menu of thousands of educational institutions, dozens of areas of study and several sources of financing for their higher education. More importantly, there is growing evidence suggesting that students engage in suboptimal enrollment and financing decisions ${ }^{1}$. In addition, despite personal finance education mandates for high school students are increasingly popular in the U.S. ${ }^{2}$, there is little evidence on the extent to which they improve career choices, which is arguably the main financial decision faced by young individuals. In particular, although several studies use survey data to assess the level of financial literacy of high school and college students ${ }^{3}$, these efforts provide little evidence on the extent to which they have specific knowledge about financial aspects of their higher education.

\footnotetext{
${ }^{1}$ For instance, Bettinger et al (2012) finds that low income individuals who received a streamlined process to complete the Free Application for Federal Student Aid (FAFSA) for themselves or their children were more likely to apply for financial aid, enroll and persist in college. A large fraction of high-achieving low income students do not attend selective schools partly because of lack of information about their opportunities at these institutions (Avery and Hoxby, 2013; Hoxby and Turner, 2014). Similarly, many low income students rely on credit card debt when they could instead borrow federal subsidized loans (Avery and Turner, 2012) and nearly one third of undergraduate students who were eligible to receive between up to $\$ 4,300$ in Pell Grants from the federal government in 2007-2008, did not apply.

2 As of March 2014, 17 (22) states require that high school students take a personal finance (economics) class in high school (Council of Economic Education, 2014).

${ }^{3}$ Some examples of this literature are Chen and Volpe (1998), Bernheim, Garrett and Maki (2001), Mandell (2009), Lusardi, Mitchell and Curto (2010) and Cole, Paulson and Shashtry (2013).
} 
The first question I study in this paper is to what extent are students familiar with the financial aspects of their higher education? Specifically, I consider three main financial aspects of this investment: future income, financing costs and opportunity cost of being enrolled. The main ingredient for this analysis is a rich survey and administrative data set of students who received financial aid from the Scholarship Foundation of St. Louis (SF), which is one of the largest U.S. non-profit organizations that provides grants, interest-free loans and financial advice to low income individuals from the St. Louis area. Overall, I find that students are poorly informed about the main financial aspects of higher education. Indeed, only one out of three students has ever tried to determine the monthly income they will earn within the first two years of graduation; one out of four students correctly ranks the costs of major sources of funding available to them; and, one out of four students considers as a cost the income they would forego if they need one extra year to earn their degree.

This low level of financial literacy among students in the sample is surprising for a number of reasons. First, these students are academically talented. Their average ACT score is 23 points (or 68 percentile in the national rank) ${ }^{4}$, their average high school GPA is 3.4 and 72 percent of them received some recognition for their academic achievements in high school. Second, 85 percent of the students in the sample passed a semester-long personal finance class in high school, which is a high school graduation requirement for students in the Missouri public education system $^{5}$. Furthermore, 69 percent of the students who took this class passed it with an "A" grade. Third, more than half of the students have work experience and thus have received income from work. Fourth, all students received an acceptance letter from a post-secondary institution and thus have been exposed to different sources of financing for their higher education, including scholarships and federal loans. In addition, nearly 40 percent of the students passed the entrance counseling for

\footnotetext{
4 This figure is based on high school students who took the ACT test and graduated in the period 2011-2013. Source: http://www.actstudent.org/scores/norms1.html, accessed on 2/19/2014.

${ }^{5}$ Missouri is one of the 17 states in the U.S. in which passing a personal finance class is a high school graduation requirement (Survey of the States, 2014).
} 
federal loans, which describes the terms and conditions associated with the use of those loans. Fifth, nearly two thirds of the students in the sample have at least one member in their family who is or has been enrolled in a post-secondary institution.

I also find that the association between the level of knowledge about financial aspects of higher education with academic achievement, exposure to different sources of financial education, financial experiences, socioeconomic and demographic characteristics is small.

Having established that students are poorly informed about financial aspects of their higher education, I address a second question: to what extent does financial education that focuses on future income, costs of different sources of financing and the opportunity cost of staying too long in college, affect students' academic performance and ability to receive financial aid? One the one hand, this financial education can increase academic effort by increasing students' awareness about their potential returns to education and de-biasing the beliefs of students who underestimate the opportunity cost of non-academic activities such as leisure and paid work. Similarly, since most students are not aware of the costs of different sources of financing for higher education, students who participate in the workshop can be more likely to keep in good standing with institutions that provide meritbased financial aid. In particular, participation in the workshop can improve the quality of applications to renew the financial aid from the SF because it offers the loan with lowest interest rate and least stringent terms available to students in the sample ${ }^{6}$. An alternative hypothesis is that financial education on the main financial aspects of higher education will not change the way in which students invest in their human capital. This can be the case, for instance, because the social and institutional environment in which students are involved provides them with the right incentives to allocate their time and effort across different activities, including study and applications for financial aid.

\footnotetext{
${ }^{6}$ The average financial aid package for renewing students was $\$ 6,767$ in total $(\$ 817$ of which are from grants and $\$ 5,950$ from interest-free loans). Raising this capital from unsubsidized federal loans, the next cheapest alternative source of financing available to these students, would increase their financing costs by about $\$ 6,000$ over a 10 year repayment period.
} 
I consider a randomized controlled trial that provided a financial education workshop to students who received financial aid from the SF for the first time during the fall of 2012 and 2013. The main topics covered were future income, the cost of different sources of financial aid and the opportunity cost enrollment. Instructors particularly emphasized the financial aspects associated with different uses of time (work versus study) and the cost differences among different sources of financial aid. The workshop was one hour long and the format was a traditional lecture. The impact evaluation of the workshop on academic performance and financial aid is only based on students who were first-time recipients of financial aid in the fall of 2012 and renewed this aid in the cycle January - April 2013. At the time of this study, I do not have yet academic and financial aid data for students who were first-time recipients of financial aid in the fall of 2013 because the deadline to submit their renewals is April 15th, 2014.

I find that participation in the workshop increases the average college GPA by 0.2 points, obtained as the difference between 3.2 points in the treatment and 3.0 points in the control group. Although the magnitude of this estimate is one third of a standard deviation of the college GPA in the sample, the p-value is only $15 \%$. In addition, I find that students who participated in the workshop are 11 percentage points more likely to receive grants and interest-free loans from the SF for a second year. The p-value of this point estimate is $25 \%$. Overall, this evidence on the impacts of the workshop is inconclusive due to the small sample size (120) of the first round of the experiment. However, if the results of the second cohort of students who participated in this experiment were the same than those from those who participated in the first round, the effects would be significant at conventional levels of significance. Since the experimental conditions of both cohorts of students are similar, in terms of students' observable characteristics and exposure to the workshop, there is a high chance to observe significant effects with a larger sample size.

This paper contributes to the literature that studies financial literacy and its determinants. The main contribution to this literature is that I provide new 
measures of financial literacy related to investments in higher education, a main financial decision faced by young individuals. Second, this paper is related to a growing literature documenting the presence of suboptimal choices in the way low income students make their enrollment and financing decisions (Avery and Hoxby, 2013; Avery and Turner, 2012; Bettinger et al., 2012; Hoxby and Turner, 2014). In particular, the results in this paper suggest that financial literacy can be an explanation for several puzzling facts documented in this literature ${ }^{7}$. Third, this paper also contributes to a growing literature documenting the effects of financial education (e.g. Willis, 2010; Fernandes, Lynch and Netemeyer, forthcoming) and financial education mandates in the U.S. (Bernheim, Garrett and Maki, 2001; Mandell, 2009; Carlin and Robinson, 2012; Cole, Paulson and Shashtry, 2013; Hastings, Madrian and Skimmyhorn, 2013; Brown, van der Klaauw, Wen and Zafar, 2014). In particular, I provide evidence on the heterogeneity of contents covered by different high schools and also the low level of awareness about the financial aspects of higher education of students who passed these classes. Fourth, and more broadly, the results of the randomized field trial suggest a new potential underlying mechanism to understand the relation between financial literacy and wealth accumulation (Lusardi and Mitchell, 2007; Behrman, Mitchel, Soo and Bravo, 2012): investments in higher education. Finally, this paper also contributes to the vast literature on human capital accumulation by challenging the core assumption that individuals understand and take into consideration the three main financial aspects of higher education: future income, financing costs and opportunity cost of schooling.

\footnotetext{
${ }^{7}$ For instance, Bettinger et al (2012) finds that low income individuals who received a streamlined process to complete the Free Application for Federal Student Aid (FAFSA) for themselves or their children were more likely to apply for financial aid, enroll and persist in college. A large fraction of high-achieving low income students do not attend selective schools partly because of lack of information about their opportunities at these institutions (Avery and Hoxby, 2013; Hoxby and Turner, 2014). Similarly, many low income students rely on credit card debt when they could instead borrow federal subsidized loans (Avery and Turner, 2012) and nearly one third of undergraduate students who were eligible to receive between up to $\$ 4,300$ in Pell Grants from the federal government in 2007-2008 did not apply.
} 
The rest of the paper is organized as follows. In section 2, I describe the data. In section 3 , I show the extent to which students are knowledgeable about the financial aspects of their higher education and its relationship with academic achievement in high school, exposure to financial education and financial experiences. In section 4, I present the results of a randomized controlled trial that evaluates the effect of the financial literacy workshop on students' academic performance in college and their ability to receive financial aid one year after the workshop. In section 5, I provide a discussion about the results. Conclusions are in section 6 .

\section{Data}

\section{a. Sources of Data and Institutional Context}

I use survey and administrative data from the Scholarship Foundation of St. Louis $(\mathrm{SF})^{8}$. The $\mathrm{SF}$ is one of the largest American non-profit organizations that provides grants, interest-free loans and financial advice to low income students in order to help them to finance their higher education. Grants and interest-free loans have to be renewed on a yearly basis. In a calendar year, the SF has two application cycles: January $1^{\text {st }}-$ April $15^{\text {th }}$ and August $1^{\text {st }}-$ November $15^{\text {th }}$. The sample is from students who meet two conditions: (i) submitted an application to the SF for the first time in January - April 2012, August - November 2012 or January - April 2013, and (ii) were selected to receive grants and interest-free loans.

Complete applications include a comprehensive application form, high school transcripts, the Free Application for Federal Financial Aid (FAFSA), the award letter from the post-secondary institution where the student is enrolling in, essays and recommendation letters. From the application form, I obtain socioeconomic and demographic information: age, ethnic origin, whether someone else in the student's family has ever attended college and self-reported ACT scores. I use high school

${ }^{8}$ http://www.sfstl.org/ 
transcripts to obtain students' GPA, average GPA in math courses, information on whether they took a personal finance class and the grade in that class. I use the FAFSA to find financial information such as the expected family contribution $(\mathrm{EFC})^{9}$ to student's higher education. From the award letter, I extract information about students' cost of attendance (tuition + room \& board) and financial aid package provided by the university.

The selection process for eligible ${ }^{10}$ students is based on three main criteria: academic potential, financial need and personal character. Academic potential is measured by grades in high school, ACT scores and academic awards. Financial need is defined as the cost of attendance minus the amount of grants, minus the amount of subsidized loans from the Federal Government and minus the EFC ${ }^{11}$. The SF provides interest-free loans to students whose financial need is greater than zero and smaller than the maximum loan amount. The maximum loan amount for the years 2012 and 2013 was $\$ 7,000$ and $\$ 9,000$ respectively. The third evaluation criterion, character, is determined by developing an overall impression of the student as represented by his or her essays, work experience, volunteer activities and recommendation letters. Some of the attributes considered in this evaluation are evidence of responsible borrowing, responsibility, honesty, good judgment, involvement and evidence of sufficient self-expression to succeed in the chosen field.

Students who are selected to receive grants and interest-free loans for the first time are required to attend a one-hour orientation session at the SF's main building. In this orientation, staff members of the SF explain the conditions of the loan, the services available to students and also hand out a check with the financial aid that students were awarded. In addition, since the year 2012, the SF has administered financial literacy surveys to students attending orientation sessions.

\footnotetext{
9 The EFC is calculated by the U.S. Department of Education based on information provided by the students in the FAFSA. For additional information, see: https://fafsa.ed.gov/help/fftoc01g.htm (accessed on 2/26/2014).

${ }^{10}$ A description of the eligibility requirements can be found at http://www.sfstl.org/financial-aid/whois-eligible, accessed on 2/26/2014.

11 Note that unsubsidized loans are not considered in its calculation of financial need because the SF wants students to rely exclusively on grants, subsidized loans and their interest-free loan.
} 
This survey includes the questions I consider to examine the extent to which students understand and take into consideration the financial aspects of their higher education. In addition, during the sample period, nearly half of the students were randomly selected to participate in a financial literacy workshop that provided education about the main financial aspects of higher education. At the end of this workshop, the SF also administered a second financial literacy survey to measure the extent to which students learned the main contents covered in the workshop.

\section{b. Descriptive Statistics}

Table 1 presents descriptive statistics of the sample of students who were first time recipients of grants and interest free loans from the SF. In Panel (a), I start considering socioeconomic and demographic characteristics. Overall, 63\% of the students are female and $43 \%$ Afro-American. The average expected family contribution (EFC) for higher education is $\$ 2,814$ and $37 \%$ of the students participated in preparatory programs for low income students in high school ${ }^{12}$.

Panel (b) provides descriptive statistics about students' current enrollment. Note that $73 \%$ of the students are freshmen, $77 \%$ are pursuing a bachelor degree and the average cost of attendance is $\$ 26,485$.

In Panel (c), I provide descriptive statistics on the academic performance of students in high school. The average ACT score is 23 points (68 percentile in the national rank), the average high school GPA is 3.4 and 71 percent of them received an academic recognition in high school.

Finally, Panel (d) presents a characterization of students' exposure to financial education and financial experiences. I find that 85 percent of the students in the sample passed a semester-long personal finance class in high school as part of their graduation requirements in the Missouri public education system. In addition,

\footnotetext{
12 Preparatory programs are conducted by non-profit organizations in St. Louis in order to help students to be admitted into post-secondary institutions. These programs provide training to improve performance in national tests, financial education and financial resources.
} 
71 percent of the students who took this class passed it with an "A" grade. 43 percent of the students passed the entrance counseling for federal loans, which is an online training that describes the terms and conditions related to the use of those loans. More than half of the students have working experience and thus have received income from work. Finally, nearly two thirds of the students have at least one other member of the family who is or has been enrolled in a post-secondary institution.

\section{Financial Literacy and Investments in Higher Education}

\section{a. Level of Financial Literacy}

In this section, I examine the extent to which low income students are familiar with three main financial aspects of their higher education: expected income, financing costs and opportunity cost of being enrolled in a post-secondary institution. The data is from the financial literacy surveys administered by the SF during the orientations of 2012 and 2013 described above.

The results discussed in this section are in Table 2. Note that the number of respondents is smaller than the number of students who received grants and loans because not all students attended the group orientation sessions. In addition, the number of respondents from the application cycle January - April 2012 is particularly small because the survey was only administered to students who participated in the financial literacy workshop.

Expected Earnings. Panel (a) reports the fraction of students who have ever thought about future income. Specifically, the wording of the question I consider is: "Have you ever tried to determine the monthly income that you will earn within the first two years of graduation? (a) Yes, (b) No" I find that only one out of three students has ever thought about how much they will earn after graduation.

Financing Costs. Panel (b) presents the fraction of students that correctly responded to the questions that measure their level of knowledge about the costs of 
different sources of financing for their higher education. The first survey question examines whether students are familiar with the interest rate of federal loans. The question was asked to students from the three application cycles considered in this study. The specific wording of the question is: "Regarding federal subsidized loans available for the next academic year, what will be the interest rate during the repayment period? (Your best guess is fine)" I find that only 18 percent of the students provided a correct answer to this question. This result is surprising because students in the sample have been exposed to the cost of federal loans in at least two ways. First, the main purpose of completing the FAFSA is to receive financial aid from the Federal Government. Second, the award letter of the postsecondary institution has a financial aid package that includes federal loans for most, if not all, students.

Although students might not be familiar with the actual interest rates of federal loans, they can still be able to compare the costs of different sources of financing available to them. In order to address this possibility, the financial literacy survey administered in the second application cycle included a hypothetical question that addresses students' cost comparison skills. The specific wording of the question is: "Suppose you need to raise $\$ 5,000$ to finance your next academic year. In the following choices, assign numbers from 1 (cheapest) to 7 (most expensive) to rank the cost of the following alternatives: (a) Grants, (b) Unsubsidized loans from the Federal Government, (c) Loan from the SF, (d) Credit Card, (e) Scholarships, (f) Subsidized loans from the Federal Government (g) Private loans". Overall, the results suggest that students are poorly informed about the relative costs of different sources of financing for their higher education. Indeed, only 23 percent of the students correctly ranked the five cheapest sources of financing available to them (in order): grants and scholarships, loan from the SF, subsidized loans and unsubsidized loans. One notable result is that 80 percent of the students said that grants and scholarship are the cheapest sources of financing for their higher education. In other words, one out of five students does not know that grants and 
scholarships are cheaper than loans. In addition, only 58 percent of the students know that subsidized loans are cheaper than unsubsidized loans.

Opportunity Costs of Enrollment. Finally, I study the extent to which students understand the opportunity cost of being enrolled in a post-secondary institution. The first survey question I use is: "Suppose your studies take one year longer than you expect. How much do you expect this additional year of studies will cost you? (Your best guess is fine)" The results in Panel (c) show that the average amount reported $(\$ 22,315)$ is slightly lower than the cost of attendance $(\$ 26,485)$. In order to determine the elements that students consider in their calculation, the financial literacy survey administered to students who applied in the cycle January - August 2013 added a follow-up question: "In the following list, please indicate the item(s) you considered to calculate the answer to the previous question: (a) total amount of tuition, (b) tuition minus grants and scholarships, (c) a year of salary, (d) cost of meals, (e) other (specify)" The most popular choice among students is the amount of tuition, with an incidence of 94 percent. However, only one out of four students considers as a cost the income they would forego if they need one extra year to earn their degree, which is arguably the largest component of the opportunity cost of enrollment.

Summing up, the results of the survey suggest that students are poorly informed about three key financial aspects of their investments in higher education: expected income, financing costs and opportunity costs of being enrolled. In the next sub-sections, I examine how these results vary with a rich set of student characteristics.

\section{b. Financial Literacy and Academic Achievement in High School}

The first potential factor associated with financial literacy is academic performance in high school. Indeed, measures of academic achievement in high school such as cumulative GPA and ACT scores are highly correlated with measures 
of general intelligence or IQ (e.g. Koenig, Frey and Detterman, 2008). In addition, there is a growing literature showing that higher cognitive skills are associated with improved financial decision making (e.g. Stango and Zinman, 2009 and 2011; Grinblatt, Keloharju and Linnainmaa, 2011 and 2012; Agarwal and Mazumder,

2013). In this study, I consider four proxies for academic achievement in high school: ACT scores, cumulative GPA, cumulative GPA in math courses and whether students received any academic recognition in high school. The results are in Table 3. I find that students with high (above the median) ACT have a slightly higher level of financial literacy across the three dimensions considered: expected income, financing costs and opportunity costs of enrollment. Cumulative GPA and math GPA do not have a clear association with the level of financial literacy. On the one hand, students with higher cumulative GPAs are slightly less likely to think about future earnings and financing costs but slightly more likely to consider expected income as a cost of taking one extra year to earn their degree. Overall, the association between academic achievement in high school and knowledge about financial aspects of higher education is small.

\section{c. Financial Literacy and Exposure to Financial Education}

The second potential factor associated with financial literacy is exposure to financial education and financial experiences. In Table 4, I find that students who were exposed to entrance counseling for Federal Loans are slightly more likely to have thought about future income but less informed about the cost of different sources of financing and the opportunity cost of higher education. I find that students who passed their personal finance class with an "A' are slightly more likely to have thought about future income and be better informed about the opportunity cost of being enrolled in a post-secondary institution. In addition, in Table 5, I find that students who took a personal finance class that covered topics related to financing of higher education and employment perspectives are slightly better informed about the financial aspects of their higher education. In contrast, students 
whose personal finance courses covered budgeting, bank accounts and credit cards do not present higher levels of financial literacy. Similarly, Table 6 shows that the level of financial knowledge does not have major differences for individuals with financial experiences such as working exposure and whether other members of the family have ever attended a post-secondary institution. Overall, the association between exposure to different sources of financial education and financial experiences with financial knowledge about the financial aspects of higher education is small.

\section{How does Financial Education affect Investments in Higher Education?}

Having established that students are poorly informed about the financial aspects of their higher education, I examine the extent to which financial education that provides information about future income, relative costs of different sources of financing for higher education and the opportunity cost of taking too long in college affects academic performance and ability to receive financial aid. Specifically, the

first outcome of interest is the GPA that students received in their post-secondary institution six months after they received financial aid from the SF. There are at least two potential mechanisms through which a financial literacy workshop on the financial aspects of higher education can improve academic performance. First, the workshop can increase academic effort by increasing students' awareness about their potential returns to education, which only a third of the students in the sample has ever thought about. Second, since most students neglect the opportunity cost of being enrolled in a post-secondary institution, the workshop can increase academic effort by helping them realize that they underestimate the true cost of non-academic activities such as leisure and paid work.

The second outcome of interest is students' ability to receive grants and interest-free loans from the SF for a second year. As discussed above, the workshop can increase the chances that students continue receiving financial aid from the SF 
and other sources of merit-based aid by improving academic performance. Second, one of the subjects that was emphasized in the workshop is that interest-free loans from the SF are cheaper and have less stringent terms than other loans available to them. Since most students are not aware of the costs of different sources of financing for higher education, I expect that those who participated in the workshop will be more likely to submit a renewal application and also work harder to meet the selection criteria. Indeed, the average financial aid package for renewing students was $\$ 6,767$ ( $\$ 817$ of which are from grants and $\$ 5,950$ from interest-free loans). Raising these funds from unsubsidized federal loans, the next cheapest alternative source of financing available to these students, would increase their financing costs by about $\$ 6,000$ over a 10 year repayment period. Thus, receiving financial aid from the SF is an economically meaningful outcome for students in the sample.

\section{a. Experimental Design}

I consider a randomized controlled trial to identify the effects of a financial education workshop provided to students who submitted their application to the SF for the first time in the cycle January - April 2012. Students in the control group were asked to attend one of the hour-long orientation sessions where staff members of the SF explained the terms of the interest-free loan and other resources available to them. Students in the treatment group were asked to participate in one of the two-hour orientation sessions. In the first hour, they received the same information that students in the control group. In the second hour, students in the treatment group participated in a financial literacy workshop that covered topics related to

future income, costs of different sources to finance higher education and the opportunity costs of being enrolled in a post-secondary institution.

Students were randomly assigned into a treatment and control group for the experiment. For practical reasons, the randomization was implemented over the group of shortlisted students, i.e. a larger group than the one that actually received 
financial aid from the SF. Indeed, as soon as students were selected for financial aid, they received an award letter that included a schedule with the orientation session they were asked to attend. The results of the randomization for students who finally received financial aid from the SF are in Panel (a) of Table 8. Note that the randomization produced a similar sample size for the treatment and control groups (73 and 78 respectively). In addition, consistent with a successful randomization procedure, I find no systematic differences across a rich set of observable characteristics: socioeconomic, demographic, current enrollment, academic performance in high school and exposure to financial education and financial experiences.

\section{b. Compliance with the Treatment}

There are two factors that affected the compliance of students with the assignment to the treatment. First, 34 students did not participate in regular orientation sessions because they entered late into the program and they were not eligible for selection into sessions with and without a financial literacy workshop. At this stage, only one-hour orientation sessions were available. The main reason for the delay was that students received late acceptance letters from the post-secondary institution they were planning to attend. Second, time conflicts or unexpected circumstances prevented students from attending the orientation session they were asked to attend. In particular, eight students who were assigned into the treatment group participated in the orientation sessions of students in the control group. Similarly, one student assigned to the control group participated in the orientation session for students in the treatment group. Panel (b) of Table 8 presents the descriptive statistics of students who participated and did not participate in the financial literacy workshop. 


\section{c. Financial Literacy Workshop}

The financial literacy workshop was one hour long. The main topics covered were future income, the cost of different sources of financial aid and the opportunity cost enrollment. The specific contents of the workshop were developed and taught by staff members of the SF and the Missouri Council of Economic Education.

The format was a traditional lecture in which instructors conducted the class using slides. The class started with a motivation in which instructors asked students whether they have ever thought about these financial aspects of their higher education ${ }^{13}$. Next, the instructor discussed the amount of loans from the SF and subsidized loans from the Federal Government that students were expected to take during their studies and their most likely repayment schedule. The instructor recalled that the SF calculated their loan and grant award in a way that, together with scholarships from other sources and subsidized loans from the Federal Government, they will have enough resources to pay for their educational expenses (tuition + room \& board). The instructor also encouraged students not to take more debt than they needed and to always look for the cheapest source of funding. Instructors also asked students not to take too little debt because they can find themselves in a situation where (i) they have to rely on more costly sources of debt or (ii) take paid jobs that might compromise their academic performance.

The class continued with a discussion about the costs associated with taking too long to earn a degree. Specifically, the instructor emphasized the work/study trade-off and the cost of replacing debt with paid jobs. The main message was that although work experiences can improve career opportunities, working too much can come at the cost of compromising academic performance. The instructor spent considerable time discussing the opportunity cost of staying too long in college, with particular emphasis on the income they would forego for not participating in the labor market, which is neglected by most students. The workshop concluded with a summary of the recommendations discussed in the class. After the class was ended,

${ }^{13}$ During the class, most students replied "no" to this question. 
students were asked to complete a voluntary follow-up survey to measure their degree of learning.

\section{d. Results}

The first outcome of interest is academic performance. The measure of performance is the GPA obtained by the student in his or her post-secondary institution. This information is from the transcripts that students submitted to the $\mathrm{SF}$ as part of their renewal application. The results are in Table 9, Panel (a). The first column presents the regression of GPA on "ITT" (intent-to-treat), a dummy that takes the value 1 for individuals who were initially selected into the treatment group and zero otherwise. I find that selection into the financial literacy workshop increases the first year by nearly 0.2 points. This effect is significant at the 10 percent level and the magnitude is equivalent to one third of a standard deviation of the average GPA in the sample.

The main limitation of the previous result is the presence of non-compliers in the data. I address this concern using an instrumental variable strategy. Specifically, I use the dummy ITT as an instrument for the actual participation of students into orientation session. By construction, ITT is a valid instrument for participation into the treatment because (i) ITT is uncorrelated with the outcome of interest through factors other than participation in the workshop and (ii) ITT strongly predicts participation in the workshop. Although (i) is not testable, the results of Panel (a) - Table 8 suggest that the randomization was successful. Assumption (ii) is confirmed in the first stage of the instrumental variable strategy reported in Column (2). As expected, the correlation between ITT and the actual treatment variable is large (0.84) and highly significant. The results of the second stage are in Column (3). I find that participation in the workshop increases the average college GPA by 0.2 points, from 3.0 in the control group to 3.2 in the treatment group. Although the magnitude of this effect is one third of a standard deviation of the overall GPA, the point estimates are only significant at the $15.4 \%$, 
probably due to the small size of the sample $(\mathrm{N}=117)$. However, a second wave of the experiment was conducted for students who applied in the cycle January - April 2013. If the results of the experiment conducted in this cycle replicate the results from students who applied in the cycle January - April 2012, then the average treatment effects on students who participated in the workshop (the treated) will be statistically significant at conventional levels of significance. Since there are no major differences among students from both cohorts (Table 1), this is likely to be the case.

The second outcome of interest is "Renew", a dummy variable that takes the value one for students who received grants and interest-free loans from the SF for a second year. The results are in Table 9, Panel (b). The first column presents the regression of "Renew" on "ITT". The point estimate is 7 percentage points and insignificant at conventional levels of significance. Again, I address the noncompliance challenge with an instrumental variable strategy in which I use ITT as an instrumental variable for the indicator of actual participation into the program. In column (3), I present the results of the second stage. The point estimates suggest that participation in the financial literacy workshop increases by about 11 percentage points (or 17\%) the probability that students are able to receive grants and interest-free loans for a second year. This effect is insignificant at conventional significance levels. However, if the results of the experiment conducted for students from the cycle January - April 2013 mimic the results of the students from the cycle January - April 2012, then the average treatment effects of the financial literacy workshop on participant students would be statistically significant at conventional significance levels. 


\section{Discussion}

\section{a. Why do students know so little about the financial aspects of their higher education?}

The results of the survey suggest that students are poorly informed about three key financial aspects of their investments in higher education: future income, financing costs and opportunity costs of being enrolled. Surprisingly, this phenomenon is observed in a group of academically talented students who were exposed to different sources of financial education and financial experiences. Why do these students know so little about the financial aspects of their higher education? I provide three potential (and non-mutually exclusive) explanations.

The first explanation is that financial education programs available to students did not encourage them to think about the main financial aspects of their higher education. This can occur because instructors believe that (i) these contents will only benefit the minority of students in their school who are college bound, (ii) students will receive this advice through an alternative channel or (iii) are not aware that this is the main financial decision faced by high school students and the potential impact of this education on financial decision making.

I examine the contents covered in the semester-long personal finance classes that students in the sample took in high school. This data is from the financial literacy survey administered to students who applied to the SF in the cycle January - April 2013, were selected to receive grants and interest-free loans and participated in the orientation sessions. Specifically, the survey question I consider is: "Please indicate what of the following topics you covered in the personal finance (or economics) class you took in high school: (a) credit cards, (b) savings accounts/debit cards, (c) budgeting, (d) alternatives to pay for higher education, (e) federal loans, $(f)$ employment and income perspectives." I find that few students recall having covered topics related with the financial aspects of their investments in higher education. Indeed, Table 5 shows that only $34 \%$ of the students covered 
alternatives to pay for higher education, 36\% studied federal loans and 53\% studied employment and income perspectives. Only $20 \%$ of the students covered these three topics during their personal finance or economics class. Overall, the results are consistent with the idea that most personal finance classes in high school do not induce students to perform a cost-benefit analysis of their investments in higher education.

A second potential explanation is that students were prompted to think about the financial aspects of their higher education but have a limited ability to recall. If financial aspects of higher education were not emphasized enough or in the right way, or were not considered in assignments or tests, then it is less likely that students will recall, which is also consistent with the survey data. A similar result can arise if students have a low ability to retain. This can occur because students only prepare these topics to perform well in tests but not to evaluate their own career choices.

A third possibility is that students do not evaluate the financial costs and benefits associated with their higher education because vocational and other nonpecuniary considerations outweigh the financial considerations of their career choices. Indeed, for many students, the non-pecuniary benefits of higher education can be as large as pecuniary benefits (Oreopoulos and Salvanes, 2011). In addition, there is growing evidence suggesting that non-academic factors (such as sports) can have a large impact on student application decisions. For instance, Pope and Pope (2014) find that a school that has a stellar year in basketball or football on average receives up to $10 \%$ more $\mathrm{SAT}$ scores.

\section{b. Impact of the Financial Literacy Workshop}

Overall, the evidence on the impacts of the workshop is inconclusive due to the small sample size of the first round of the experiment. If the results of the second cohort of students who participated in this experiment were the same than those from those who participated in the first round, the effects would be significant 
at conventional levels. Since the experimental conditions of both cohorts of students are similar, in terms of students' observable characteristics and exposure to the workshop, there is a high chance to observe significant effects with a larger sample size.

If the analysis of a larger sample confirmed these effects, one question that arises is: how can one hour of financial education have such large effects on academic performance and the ability to receive financial aid? This is particularly relevant because students in the sample have already been exposed to different sources of financial education and several studies show that financial education has minor effects on financial literacy and financial behavior (Fernandes, Lynch and Netemeyer, forthcoming) ${ }^{14}$. There are two main set of factors that can explain positive and significant effects of the workshop: (i) contents and (ii) characteristics and circumstances of participant students. In order to illustrate this point, I examine the way in which this workshop and circumstances of the participant address the main barriers to financial education programs identified in the literature (e.g. Willis, 2010; Fernandes, Lynch and Netemeyer, forthcoming).

The first barrier to financial education is that many individuals have limited capabilities to perform basic math tasks and to retain knowledge, which are necessary skills to understand and evaluate financial choices. In this experiment, most students in the sample are able to perform the basic math operations that are necessary to understand the main financial aspects of higher education discussed in the workshop. Similarly, students' ability to retain knowledge is strengthened with a financial education program specifically designed to connect the contents to the specific circumstances that they face.

Second, there is a gap between the time in which financial education is provided and the timing of financial choices related to this education. In this context, decreasing ability to retain knowledge and a changing marketplace reduce

\footnotetext{
${ }^{14}$ Fernandes, Lynch and Netemeyer (forthcoming) conduct a meta-analysis of the effect of financial literacy on financial behavior of more than 200 papers. Their main finding is that financial education has a minor role for financial literacy and financial decision making.
} 
the potential impact of financial education programs on financial decision making. In the workshop studied in this paper, this problem is mitigated because most of the education focused the costs and benefits of two actions that students have to make decisions on shortly after participating in the workshop: use of time and borrowing.

Third, the heterogeneity of individual preferences and circumstances reduce the ability of financial literacy programs to provide advice that is useful for everyone. Similarly, since the link between financial decisions and individual wellbeing is not straightforward, it is unclear that financial education will induce individuals to make similar financial choices during a specific time frame. In the context of the workshop, the education provided is relevant because (i) students have to make choices in terms of use of time and use of credit, (ii) the economic consequences of these choices are large and (iii) students were not fully aware of the consequences of their choices. In addition, the information and many of the recommendations provided during the workshop promote desirable behavior regardless of student preferences and personal circumstances ${ }^{15}$.

Another potential concern is that financial institutions could outmaneuver financial education and lead consumer into bad financial choices. This is an unlikely barrier for the program studied in this paper because it was provided to a small and disperse group of students.

\section{Conclusion}

Higher education is a key investment opportunity for young individuals. Yet, there is little known about the extent to which students understand and take into consideration the main financial aspects of this decision. Using rich administrative and survey data from a large U.S. non-profit organization, I find that students are

\footnotetext{
${ }^{15}$ For instance, a large portion of the workshop focused on encouraging students to look for the cheapest source of financing for higher education (grants and scholarships, loans from the SF and subsidized loans from the Federal Government). A second major component of the workshop aimed at helped students to understand the opportunity cost of taking too long in college, which is especially useful because most students neglect the fact that the income they would forego is a major cost for taking too long in earning a degree.
} 
poorly informed about three main financial aspects of their higher education: future income, financing costs and opportunity cost of enrollment. Indeed, only one out of three students in the sample had ever tried to determine their income within two years after earning a degree; one out of four students correctly ranked the costs of major sources of funding available to them; and, one out of four students claimed to consider as a cost the income they would forego if they need one extra year to earn their degree. This result is surprising because students in the sample are academically accomplished (high GPA and ACT scores), were exposed to financial education (semester-long personal finance class) and had real financial experiences (paid jobs and applications for financial aid).

I also examine the extent to which financial education that is focused on future income, costs of different sources of financing and the opportunity cost of enrollment affects students' academic performance and ability to receive financial aid. Using data from the first round of implementation of a randomized field experiment, I find that students who participated in an hour-long financial literacy workshop received 0.2 points higher GPA in their post-secondary institution than the control group (3.2 versus 3.0$)$. This difference has a p-value of $15 \%$ with a sample size of 117 students. In addition, I find that students who participated in the workshop were 11 percentage points more likely to receive financial aid from the non-profit organization than the control group, with a p-value of 0.25 . Overall, these results suggest that financial education that focuses on financial aspects of higher education could improve students' academic achievement and their ability to receive financial aid. 


\section{References}

Agarwal S. and B. Mazumder, 2013, Cognitive Abilities and Household Financial Decision Making, American Economic Journal: Applied Economics, 5(1): 193207

Avery, Christopher and Sarah Turner, 2012, Student Loans: Do College Students Borrow Too Much-Or Not Enough?, Journal of Economic Perspectives, 26(1): $165-192$

Behrman, Jere, Olivia Mitchell, Cindy Soo and David Bravo, 2012, How Financial Literacy Affects Household Wealth Accumulation, American Economic Review: Papers \& Proceedings, 102(3): 300-304

Bertrand, Marianne, and Adair Morse, 2011, Information Disclosure, Cognitive Biases and Payday Borrowing, Journal of Finance, 66(6), 1865-1893.

Bettinger, Eric, Bridget Long, Philip Oreopoulos and Lisa Sanbonmatsu, 2012, The role of simplification and information in college decisions: results from the H\&R block FAFSA experiment, Quarterly Journal of Economics, 127 (3): 1057-1106.

Cadena, Brian and Benjamin Keys, 2013, Can Self-Control Explain Avoiding Free Money? Evidence from Interest-Free Student Loans, Review of Economics and Statistics, 95 (4): 1117-1129.

Campbell, John, 2006, Household Finance, Journal of Finance, 61 (4): 1553-1604

Carlin, Bruce and David Robinson, 2012, Financial Education and Timely Decision Support: Lessons from Junior Achievement, American Economic Review: Papers \& Proceedings, $102(3), 305-308$.

Cole, Shawn and Bilal Zia, 2011, Prices or Knowledge? What Drives Demand for Financial Services in Emerging Markets?, Journal of Finance, 66 (6), 1933-1967

Cole, Shawn, Anna Paulson and Kartini Shastry, forthcoming, Smart money: The Effect of Education on Financial Outcomes, Review of Financial Studies.

Cole, Shawn, Anna Paulson and Kartini Shastry, 2013, High School and Financial Outcomes: The Impact of Mandated Personal Finance and Mathematics Courses, working paper. 
Council for Economic Education, 2014, Survey of the States: Economic, Personal Finance \& Entrepreneurship Education in Our Nation's Schools in 2009, www.councilforeconed.org, accessed 03/11/2014.

Fernandes, Daniel, John G. Lynch Jr. and Richard G. Netemeyer, forthcoming, Financial Literacy, Financial Education, and Downstream Financial Behaviors, Management Science.

Grinblatt M., Keloharju M. and J. Linnainmaa, 2011, IQ and Stock Market Participation. The Journal of Finance, 66 (6), pp 2119-2164.

Grinblatt M., Keloharju M. and J. Linnainmaa, 2012, IQ, Trading Behavior, and Performance. Journal of Financial Economics, 104 (2), pp 339-362.

Koenig, Katherine, Frey, Meredith and Douglas Detterman, 2008, ACT and general cognitive ability, Intelligence 36, 153-160

Lusardi, A., and P. Tufano, 2009, Debt Literacy, Financial Experiences and Overindebtedness. NBER Working Paper 14808.

Lusardi, Annamaria, and Olivia S. Mitchell, 2006, Financial literacy and planning: Implications for retirement well-being, Working paper no. 1, Pension Research Council.

Lusardi, Annamaria, and Olivia S. Mitchell, 2007, Financial literacy and retirement preparedness: Evidence and implications for financial education, Business Economics 42, 35-44.

Lusardi, Annamaria, and Olivia S. Mitchell, 2008, Baby boomer retirement security: The roles of planning, financial literacy, and housing wealth, Journal of Monetary Economics 54, 205-224.

Lusardi, Annamaria, Olivia S. Mitchell, and Vilsa Curto, 2010, "Financial Literacy among the Young." Journal of Consumer Affairs 44 (2): 358-80.

Lyons, Angela, and Urvi Neelakantan, 2008, Potential and pitfalls of applying theory to the practice of financial education, Journal of Consumer Affairs 42, $106-112$.

Mandell, Lewis, 2007, Financial Education in High School, in Annamaria Lusardi ed.: Overcoming the Saving Slump: How to Increase the Effectiveness of Financial Education and Saving Programs (SUNY-Buffalo Press). 
Oreopoulos, P. and Salvanes, K.G., 2011. Priceless: The Nonpecuniary Benefits of Schooling, Journal of Economic Perspectives, 25 (1), 159-184.

Stango, Victor, and Jonathan Zinman, 2009, Exponential growth bias and household finance, Journal of Finance 64, 2807-2849.

Stango, Victor, and Jonathan Zinman, 2011, Fuzzy math, disclosure regulation, and credit market outcomes: Evidence from Truth-in-Lending reform, Review of Financial Studies, 24 (2), 506-534.

Willis, Lauren, 2011, The financial education fallacy, American Economic Review: Papers and Proceedings, 101 (3), 429-434. 


\section{Tables}

\section{Table 1 \\ Descriptive Statistics}

Panels (a) - (e) present average characteristics of students who received grants and interest-free loans from the Scholarship Foundation of St. Louis. The application cycles considered are: January - April 2012, August - November 2012 and January - April 2013. The description of variables is in section 3(a).

\begin{tabular}{ccc} 
& \multicolumn{2}{c}{ Application Cycle } \\
Jan - Apr & Aug - Nov & Jan - Apr \\
2012 & 2012 & 2013
\end{tabular}

All

Number of grant and loan recipients

153

41

132

326

(a) Socioeconomic and Demographic Characteristics

Female

African-American

EFC $(\$ 1,000)$

Preparatory Program
0.61

0.39

2.71

0.37
0.80

0.61

2.51

0.46
0.61

0.41

3.03

0.34
0.63

0.43

2.81

0.37

\section{(b) Current Enrollment}

Freshmen

0.76

0.75

Bachelor degree

Cost of Attendance $(\$ 1,000)$

25.5

\section{(c) Academic Performance in High School}

ACT score

HS GPA

HS Math GPA

Received any recognition
3.45

3.05

0.67
0.41

0.85

20.9
0.80

0.77

29.4
0.73

0.77

26.5

\section{(d) Financial Education and Experience}

Personal Finance in HS

Grade in Personal Finance

Grade $=\mathrm{A}$ in Personal Finance

Entrance Counseling for Federal Loans

Working Experience

First member of the family who attends

a post-secondary institution

$\begin{array}{llll}0.85 & 0.88 & 0.85 & 0.85 \\ 3.63 & 3.62 & 3.68 & 3.65 \\ 0.72 & 0.71 & 0.71 & 0.71 \\ 0.40 & 0.84 & 0.37 & 0.43 \\ 0.55 & 0.78 & 0.56 & 0.58 \\ 0.32 & 0.37 & 0.37 & 0.35\end{array}$




\section{Table 2}

\section{Financial Literacy}

Panels (a) - (c) present the fraction of students that correctly answered financial literacy questions about the financial aspects of higher education. Note that the number of respondents to the financial literacy survey is smaller than the number of students who received grants and loans because not all students attended the group orientation sessions. The number of respondents for the application cycle January - April 2012 is particularly small because the financial literacy survey was only administered to students who participated in the workshop.

Application Cycle

\begin{tabular}{cccc}
\hline Jan - Apr & Aug - Nov & Jan - Apr & \multirow{2}{*}{ All } \\
2012 & 2012 & 2013 & \\
\hline & & &
\end{tabular}

Number of respondents

47

19

107

173

\section{(a) Expected Income}

Has ever thought about future income

$\begin{array}{llll}\text {. } & 0.40 & 0.32 & 0.33\end{array}$

\section{(b) Costs of Financing}

Knows the interest rate for federal subsidized loans.

0.13

0.15

0.24

0.20

Correctly ranks the costs of the following financing sources: grants, scholarships, loans from the

Scholarship Foundation, subsidized and unsubsidized loans from the Federal Government, credit cards and private loans.

Scholarships and grants are the cheapest source of financing.

The three cheapest sources of financing are (in order): scholarships, grants and loans from the Scholarship Foundation.

Federal subsidized loans are cheaper than unsubsidized loans.

The four cheapest sources of financing are (in order): scholarships, grants, loans from the Scholarship Foundation and subsidized loans from

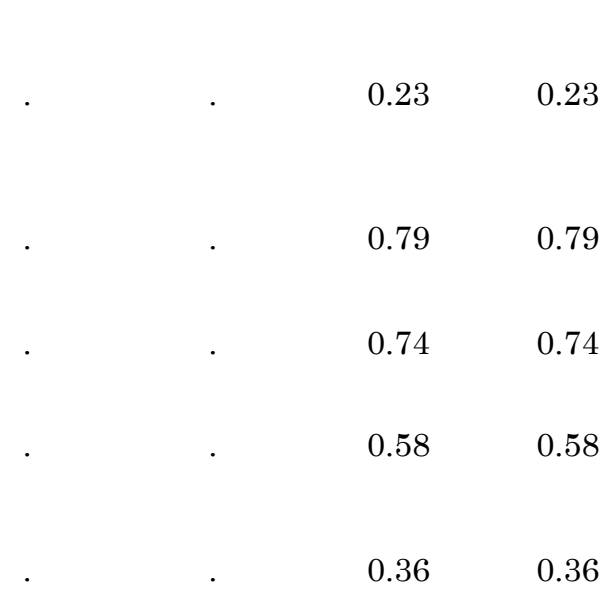
the Federal Government.

\section{(c) Opportunity Cost of Enrollment}

Cost of staying one extra year enrolled in a postsecondary institution

Tuition is one of the costs of being one extra year in college.

Foregone income is one cost of staying one extra year in college

$\begin{array}{ll}0.93 & 0.93 \\ 0.25 & 0.25\end{array}$




\section{Table 3}

\section{Financial Literacy and Academic Achievement in High School}

This table presents the fraction of students that correctly answered to the financial literacy questions according to their academic achievement. The cutoffs represent the median value of ACT, GPA and math GPA in high school respectively. The specific wording of the financial literacy questions is in section 3(a).

\section{(a) Expected Income}

Has ever thought about future income

\begin{tabular}{|c|c|c|c|c|c|}
\hline $\mathrm{ACT}<23$ & $\mathrm{ACT}>23$ & GPA $<3.5$ & GPA $>3.5$ & $\begin{array}{c}\text { Math } \\
\text { GPA }<3.0\end{array}$ & $\begin{array}{c}\text { Math } \\
\text { GPA }>3.0\end{array}$ \\
\hline 0.28 & 0.39 & 0.38 & 0.27 & 0.37 & 0.26 \\
\hline 0.18 & 0.24 & 0.17 & 0.24 & 0.19 & 0.21 \\
\hline 0.19 & 0.29 & 0.27 & 0.21 & 0.32 & 0.16 \\
\hline 0.75 & 0.84 & 0.80 & 0.79 & 0.82 & 0.73 \\
\hline 0.68 & 0.82 & 0.73 & 0.74 & 0.77 & 0.68 \\
\hline 0.58 & 0.55 & 0.57 & 0.59 & 0.59 & 0.57 \\
\hline 0.32 & 0.43 & 0.37 & 0.36 & 0.43 & 0.32 \\
\hline 0.25 & 0.27 & 0.20 & 0.29 & 0.18 & 0.30 \\
\hline
\end{tabular}
one extra year in college

knows the interest rate for federal subsidized loans.

Correctly ranks the costs of the following financing sources: grants, scholarships, loans from the Scholarship Foundation, subsidized and unsubsidized loans from the Federal Government, credit cards and private loans.

Scholarships and grants are the cheapest source of financing.

The three cheapest sources of financing are (in order): scholarships, grants and loans from the Scholarship Foundation.

Federal subsidized loans are cheaper than unsubsidized loans.

The four cheapest sources of financing are (in order): scholarships, grants, loans from the Scholarship Foundation and subsidized loans from the Federal Government.

\section{(c) Opportunity Cost of Enrollment}

\section{Foregone income is one cost of staying}

(20) 


\section{Table 4}

\section{Financial Literacy and Financial Education}

This table presents the fraction of students that correctly answered the financial literacy questions according to their exposure to the entrance counseling for federal loans and their performance in the mandatory personal finance class they took in high school. The specific wording of the financial literacy questions is in section 3(a).

\section{(a) Expected Income}

Has ever thought about future income

0.28

0.40

\section{Entrance counseling for Federal Loans}

No

\section{(b) Costs of Financing}

knows the interest rate for federal subsidized loans.

0.20

0.21

0.19

0.22

Correctly ranks the costs of the following financing sources: grants, scholarships, loans from the Scholarship Foundation, subsidized and unsubsidized loans from the Federal Government, credit cards and private loans.

Scholarships and grants are the cheapest source of financing.

The three cheapest sources of financing are (in order): scholarships, grants and loans from the Scholarship Foundation.

Federal subsidized loans are cheaper than unsubsidized loans.

The four cheapest sources of financing are (in order): scholarships, grants, loans from the Scholarship Foundation

\section{(c) Opportunity Cost of Enrollment}

Foregone income is one cost of staying one extra year in college 


\section{Table 5}

\section{Financial Literacy and Contents Covered in the Personal Finance Class}

This table presents the fraction of students that correctly answered the financial literacy according to their exposure to specific topics in the personal finance class they took in high school. The specific wording of the financial literacy questions is in section 3(a).

Number of Respondents

(a) Expected Income

Has ever thought about future income

\section{(b) Costs of Financing}

knows the interest rate for federal subsidized loans.

Correctly ranks the costs of the following financing sources: grants, scholarships, loans from the Scholarship Foundation, subsidized and unsubsidized loans from the Federal Government, credit cards and private loans.

Scholarships and grants are the cheapest source of financing.

The three cheapest sources of financing are (in order): scholarships, grants and loans from the Scholarship Foundation.

Federal subsidized loans are cheaper than unsubsidized loans.

The four cheapest sources of financing are (in order): scholarships, grants, loans from the Scholarship Foundation and subsidized loans from the Federal Government.

\section{(c) Opportunity Cost of Enrollment}

Foregone income is one cost of staying one extra year in college

\begin{tabular}{|c|c|c|c|c|c|}
\hline \multicolumn{2}{|c|}{ Credit Cards } & \multicolumn{2}{|c|}{ Bank Accounts } & \multicolumn{2}{|c|}{ Budgeting } \\
\hline No & Yes & No & Yes & No & Yes \\
\hline 24 & 82 & 13 & 93 & 15 & 91 \\
\hline 0.23 & 0.77 & 0.12 & 0.88 & 0.14 & 0.86 \\
\hline 0.42 & 0.29 & 0.54 & 0.29 & 0.47 & 0.30 \\
\hline 0.25 & 0.24 & 0.31 & 0.24 & 0.27 & 0.24 \\
\hline 0.17 & 0.24 & 0.15 & 0.24 & 0.20 & 0.23 \\
\hline 0.63 & 0.84 & 0.54 & 0.83 & 0.67 & 0.81 \\
\hline 0.63 & 0.77 & 0.54 & 0.76 & 0.67 & 0.75 \\
\hline 0.50 & 0.60 & 0.46 & 0.59 & 0.47 & 0.59 \\
\hline 0.29 & 0.38 & 0.23 & 0.38 & 0.33 & 0.36 \\
\hline 0.38 & 0.21 & 0.31 & 0.24 & 0.13 & 0.26 \\
\hline
\end{tabular}




\section{Table 5 (Continued)}

\section{Financial Literacy and Contents Covered in the Personal Finance Class}

This table presents the fraction of students that correctly answered the financial literacy according to their exposure to specific topics in the personal finance class they took in high school. The specific wording of the financial literacy questions is in section 3(a).

Observations

\section{(a) Expected Income}

Has ever thought about future income

\section{(b) Costs of Financing}

knows the interest rate for federal subsidized loans.

Correctly ranks the costs of the following financing sources: grants, scholarships, loans from the Scholarship Foundation, subsidized and unsubsidized loans from the Federal Government, credit cards and private loans.

Scholarships and grants are the cheapest source of financing.

The three cheapest sources of financing are (in order): scholarships, grants and loans from the Scholarship Foundation.

Federal subsidized loans are cheaper than unsubsidized loans.

The four cheapest sources of financing are (in order): scholarships, grants, loans from the Scholarship Foundation and subsidized loans from the Federal Government.

\section{(c) Opportunity Cost of Enrollment}

Foregone income is one cost of staying one extra year in college

\begin{tabular}{|c|c|c|c|c|c|}
\hline \multicolumn{2}{|c|}{$\begin{array}{c}\text { Financing of } \\
\text { Higher } \\
\text { Education }\end{array}$} & \multicolumn{2}{|c|}{$\begin{array}{l}\text { Employment } \\
\text { Perspectives }\end{array}$} & \multicolumn{2}{|c|}{ Federal Loans } \\
\hline No & Yes & No & Yes & No & Yes \\
\hline 70 & 36 & 49 & 57 & 67 & 39 \\
\hline 0.66 & 0.34 & 0.46 & 0.54 & 0.63 & 0.37 \\
\hline 0.29 & 0.39 & 0.29 & 0.35 & 0.31 & 0.33 \\
\hline 0.23 & 0.28 & 0.20 & 0.28 & 0.24 & 0.26 \\
\hline 0.21 & 0.25 & 0.18 & 0.26 & 0.21 & 0.26 \\
\hline 0.77 & 0.83 & 0.73 & 0.84 & 0.79 & 0.79 \\
\hline 0.73 & 0.75 & 0.67 & 0.79 & 0.78 & 0.67 \\
\hline 0.54 & 0.64 & 0.59 & 0.56 & 0.54 & 0.64 \\
\hline 0.36 & 0.36 & 0.35 & 0.37 & 0.36 & 0.36 \\
\hline 0.23 & 0.28 & 0.22 & 0.26 & 0.28 & 0.18 \\
\hline
\end{tabular}




\section{Table 6}

\section{Financial Literacy and Financial Experiences}

This table presents the fraction of students that correctly answered the financial literacy questions according to their exposure to two different financial experiences: work and having a member of the family who has ever attended a post-secondary institution. The specific wording of the financial literacy questions is in section 3(a).

\section{(a) Expected Income}

Has ever thought about future income

0.27

0.37

Work Experience

(b) Costs of Financing

knows the interest rate for federal

subsidized loans.

0.19

0.18

0.24

Correctly ranks the costs of the following financing sources: grants, scholarships, loans from the Scholarship Foundation, subsidized and unsubsidized loans from

the Federal Government, credit cards and private loans.

Scholarships and grants are the cheapest source of financing.

The three cheapest sources of financing are (in order): scholarships, grants and loans from the Scholarship Foundation.

Federal subsidized loans are cheaper than unsubsidized loans.

0.65

The four cheapest sources of financing are (in order): scholarships, grants, loans from the Scholarship Foundation

\section{(c) Opportunity Cost of Enrollment}

Foregone income is one cost of staying one extra year in college

0.28 


\section{Table 7}

\section{Financial Literacy, Socioeconomic and Demographic Background}

This table presents the fraction of students that correctly answered the financial literacy questions according to their socioeconomic and demographic background. The specific wording of the financial literacy questions is in section 3(a).

\section{(a) Expected Income}

Has ever thought about future income

\section{(b) Costs of Financing}

knows the interest rate for federal subsidized loans.

Correctly ranks the costs of the following financing sources: grants, scholarships, loans from the Scholarship Foundation, subsidized and unsubsidized loans from the Federal Government, credit cards and private loans.

Scholarships and grants are the cheapest source of financing.

The three cheapest sources of financing are (in order): scholarships, grants and loans from the Scholarship Foundation.

Federal subsidized loans are cheaper than unsubsidized loans.

The four cheapest sources of financing are (in order): scholarships, grants, loans from the Scholarship Foundation and subsidized loans from the Federal Government.

\section{(c) Opportunity Cost of Enrollment}

Foregone income is one cost of staying one extra year in college

\begin{tabular}{|c|c|c|c|c|c|}
\hline \multicolumn{2}{|c|}{ Female } & \multicolumn{2}{|c|}{ Afro-American } & \multicolumn{2}{|c|}{ Freshman } \\
\hline No & Yes & No & Yes & No & Yes \\
\hline 0.43 & 0.28 & 0.43 & 0.22 & 0.39 & 0.31 \\
\hline 0.14 & 0.24 & 0.27 & 0.12 & 0.19 & 0.21 \\
\hline 0.30 & 0.19 & 0.25 & 0.23 & 0.28 & 0.22 \\
\hline 0.85 & 0.76 & 0.79 & 0.82 & 0.92 & 0.76 \\
\hline 0.83 & 0.69 & 0.77 & 0.72 & 0.84 & 0.71 \\
\hline 0.55 & 0.60 & 0.52 & 0.69 & 0.60 & 0.57 \\
\hline 0.45 & 0.31 & 0.37 & 0.38 & 0.40 & 0.35 \\
\hline 0.23 & 0.27 & 0.31 & 0.23 & 0.24 & 0.26 \\
\hline
\end{tabular}




\section{Table 8}

\section{Randomization}

This table presents the results of the randomization. The results of the randomization for students who received financial aid from the SF are in Panel (a). Panel (b) presents the descriptive statistics of students who participated and did not participate in the financial literacy workshop. The description of variables is in section 3(a).

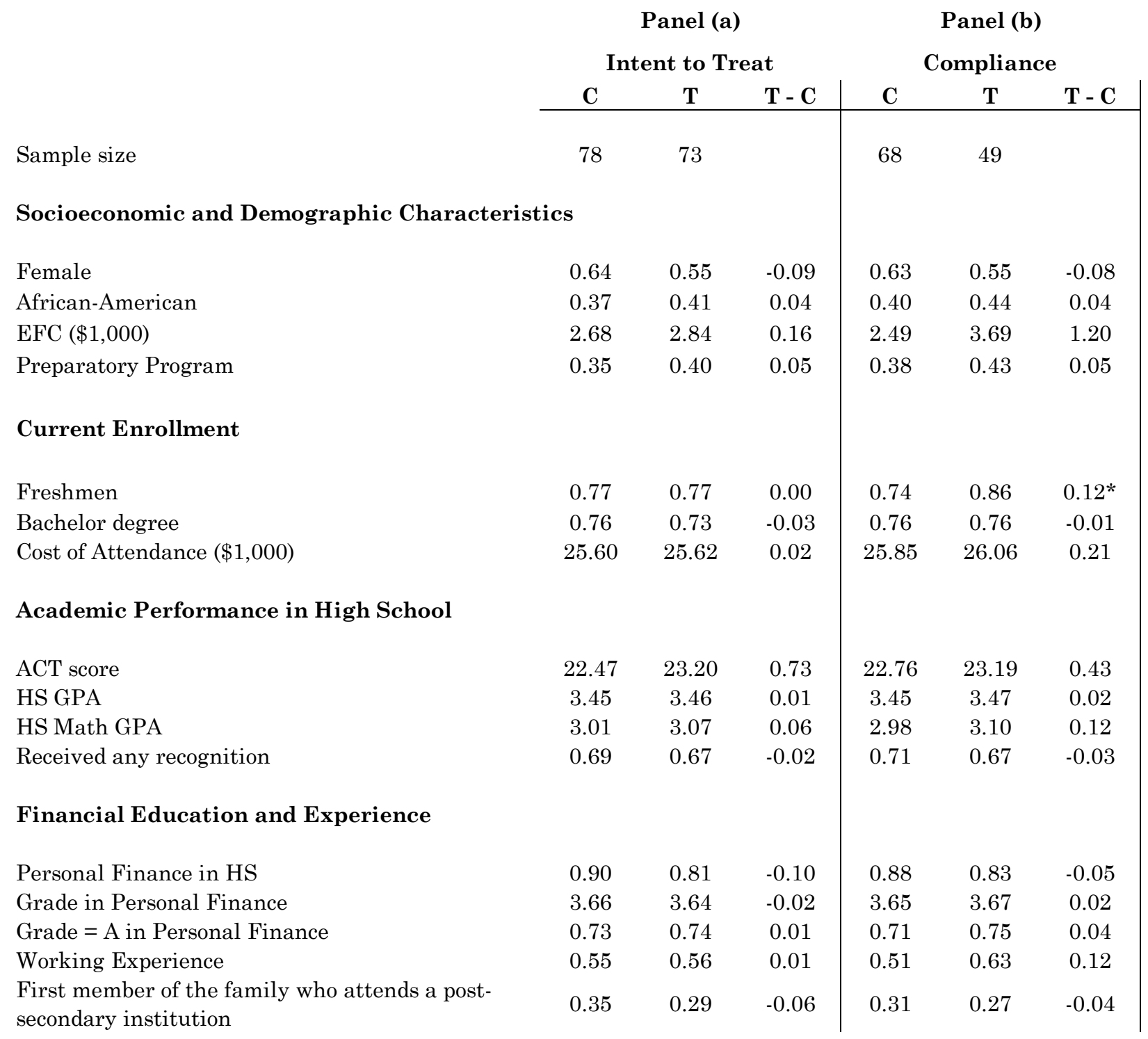




\section{Table 9}

\section{Impact Evaluation of Financial Literacy Workshop}

This table presents the incidence of correct responses for students with different socioeconomic and demographic background. The specific wording of the financial literacy questions is in section $3(\mathrm{a})$.

\begin{tabular}{|c|c|c|c|}
\hline & & el (a) & \\
\hline & $\begin{array}{c}(1) \\
\text { GPA } \\
(\mathrm{OLS}) \\
\end{array}$ & $\begin{array}{c}(2) \\
\text { Treatment } \\
\text { (IV-First stage) }\end{array}$ & $\begin{array}{c}(3) \\
\text { GPA } \\
\text { IV-Second stage }\end{array}$ \\
\hline Intent to treat & $\begin{array}{l}0.185^{*} \\
(0.087)\end{array}$ & $\begin{array}{c}0.841^{* * *} \\
(0.000)\end{array}$ & \\
\hline Treatment & & & $\begin{array}{c}0.207 \\
(0.154)\end{array}$ \\
\hline Constant & $\begin{array}{c}3.000 * * * \\
(0.000)\end{array}$ & $\begin{array}{c}0.016 \\
(0.320)\end{array}$ & $\begin{array}{c}2.990 * * * \\
(0.000)\end{array}$ \\
\hline $\begin{array}{l}\text { Observations } \\
\text { R-squared }\end{array}$ & $\begin{array}{c}128 \\
0.023\end{array}$ & $\begin{array}{c}117 \\
0.725\end{array}$ & $\begin{array}{c}106 \\
0.000\end{array}$ \\
\hline
\end{tabular}

Panel (b)

\begin{tabular}{lc|cc} 
& $\begin{array}{c}(1) \\
\text { Renew=1 } \\
(\mathrm{OLS})\end{array}$ & $\begin{array}{c}(2) \\
\text { Treatment } \\
\text { (IV-First stage) }\end{array}$ & $\begin{array}{c}(3) \\
\text { Renew=1 }\end{array}$ \\
$\begin{array}{lccc}\text { IV-Second stage } \\
\text { Intent to treat }\end{array}$ & 0.072 & $0.841^{* * *}$ & \\
Treatment & $(0.341)$ & $(0.000)$ & \\
Constant & & & 0.114 \\
& $0.654^{* * *}$ & 0.016 & $(0.250)$ \\
Observations & $(0.000)$ & $(0.320)$ & $0.670^{* * *}$ \\
R-squared & 151 & 117 & $(0.000)$ \\
\hline
\end{tabular}

